
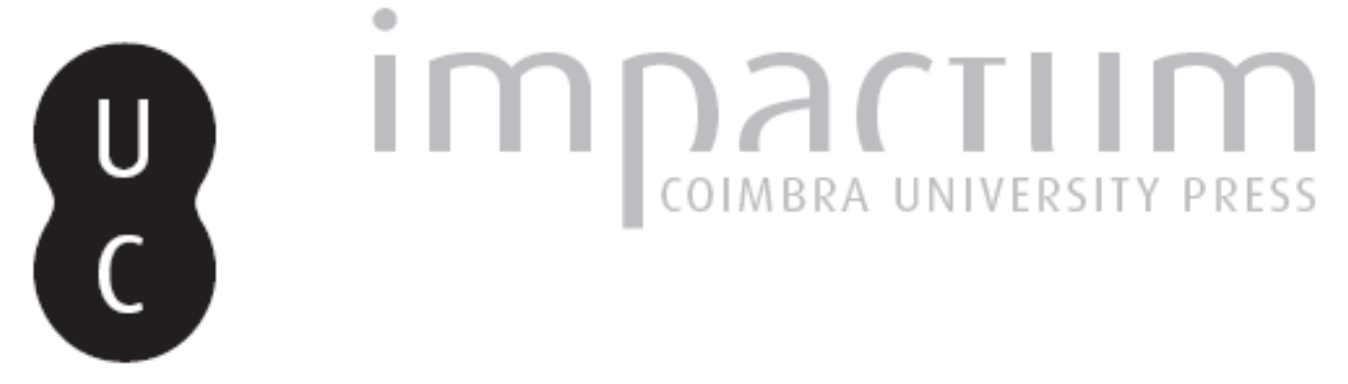

\title{
Conflitualidade anti-senhorial na época moderna: o caso de Barbacena
}

Autor(es): $\quad$ Fonseca, Teresa

Publicado por: Imprensa da Universidade de Coimbra

URL persistente:

URl:http://hdl.handle.net/10316.2/45006

DOI: $\quad$ DOI:https://doi.org/10.14195/0870-4147_38_11

Accessed : $\quad$ 26-Apr-2023 13:52:26

A navegação consulta e descarregamento dos títulos inseridos nas Bibliotecas Digitais UC Digitalis, UC Pombalina e UC Impactum, pressupõem a aceitação plena e sem reservas dos Termos e Condições de Uso destas Bibliotecas Digitais, disponíveis em https://digitalis.uc.pt/pt-pt/termos.

Conforme exposto nos referidos Termos e Condições de Uso, o descarregamento de títulos de acesso restrito requer uma licença válida de autorização devendo o utilizador aceder ao(s) documento(s) a partir de um endereço de IP da instituição detentora da supramencionada licença.

Ao utilizador é apenas permitido o descarregamento para uso pessoal, pelo que o emprego do(s) título(s) descarregado(s) para outro fim, designadamente comercial, carece de autorização do respetivo autor ou editor da obra.

Na medida em que todas as obras da UC Digitalis se encontram protegidas pelo Código do Direito de Autor e Direitos Conexos e demais legislação aplicável, toda a cópia, parcial ou total, deste documento, nos casos em que é legalmente admitida, deverá conter ou fazer-se acompanhar por este aviso.

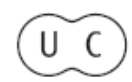



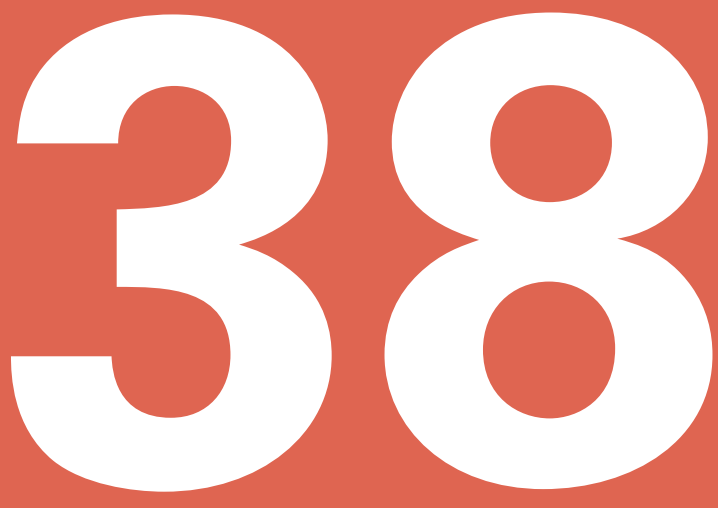

\section{Revista Portuguesa de História}

Faculdade de Letras da Universidade de Coimbra Instituto de História Económica e Social

Coimbra 08 


\section{Conflitualidade anti-senhorial na época moderna. O caso de Barbacena}

Teresa Fonseca

CIDEHUS/Universidade de Évora Bolseira de pós-doutoramento da F.C.T.

\section{Introdução}

Os conflitos anti-senhoriais, tão antigos como os próprios senhorios, agravaram-se com a progressiva integração dos concelhos nas donatarias, da qual resultaram, para os municípios, importantes perdas de jurisdição e prejuízos financeiros ${ }^{1}$.

Os monarcas promoveram diversas iniciativas no sentido da restrição dos poderes senhoriais, de modo a aplacar os confrontos das câmaras e das populações com os donatários. Porém, tais medidas não impediram estes últimos do crescente exercício de poderes e do uso de direitos, para além dos atribuídos nos títulos de doação. Entre tais arbitrariedades destacaram-se as imposições fiscais ou a usurpação de terras de uso comum, pelas atitudes de rejeição e revolta que desencadeavam nos povos ${ }^{2}$.

1 Margarida Sobral Neto, "A persistência senhorial”, História de Portugal, (dir. de José Mattoso), vol. 3, "No alvorecer da modernidade", Lisboa, Estampa, 1993, pp. 165-167.

2 Humberto Baquero Moreno, "Um conflito senhorial em Pinhel e seu termo, no século XV", Marginalidade e conflitos sociais em Portugal nos séculos XIV e XV, Lisboa, Presença, 1985, pp. 172-211. Id., "Abusos e violências na região da Beira Interior durante o reinado de D. Afonso V", 
D. Manuel I tentou atalhar tais abusos e simultaneamente controlar o poder senhorial no contexto da acção centralizadora desenvolvida no seu reinado, através de algumas medidas de fundo: definição do conteúdo de doação genérica de uma terra com os seus direitos e jurisdições ${ }^{3}$; condicionamento da atribuição de várias prerrogativas à sua menção expressa nos textos das doações ${ }^{4}$; e a reforma dos forais. No âmbito desta última medida, suprimiram-se destes diplomas concelhios normas particulares caídas em desuso ou contrárias à lei geral; adaptou-se a sua redacção às transformações sócio-económicas e políticas entretanto ocorridas; actualizaram-se pesos, medidas e prestações diversas; introduziu-se o registo dos direitos reais possuídos por donatários; registaram-se os tributos e prestações a pagar a estes, fixados em anteriores

Exilados, marginais e contestatários na sociedade portuguesa medieval, Lisboa, Presença, 1989, pp. 108-123. Maria Helena da Cruz Coelho, "Contestação e resistência dos que vivem da terra", Revista de História Económica e Social, no 18, Lisboa, Julho-Dezembro de 1986, pp. 45-56. Id., O Baixo Mondego nos finais da Idade Média, vol. I, Lisboa, INCM, 1989, pp. 239-291, 544-551 e 657-659. Cláudio Filipe de Almeida Cavaco, "Senhorios jurisdicionais laicos e movimentos anti-senhoriais em Portugal nos séculos XIV e XV”, Arqueologia do Estado. Comunicações 1, Lisboa, História \& Crítica, 1988, pp. 271-290. Francisco Ribeiro da Silva, "O foral de Cambra no conjunto dos forais manuelinos", Revista da Faculdade de Letras - História, $2^{\mathrm{a}}$ série, vol. VI, Porto, Universidade, 1989, p. 227. Jorge Fonseca, "Um levantamento contra os Távoras em Mogadouro", Brigantia - Revista de Cultura, Bragança, Assembleia Distrital, vol. XV, nº 2-3-4, Abril-Dezembro de 1995, pp. 105-108. Id., O foral manuelino do Vimieiro. Estudo e transcrição, Arraiolos, Câmara Municipal, 1999, pp. 27-28. Id., O foral manuelino de Arraiolos. Estudo e transcrição, Arraiolos, Câmara Municipal, 2000, pp. 47 e 49-52. Id., "A vila e castelo de Lavar", Almansor, $\mathrm{n}^{\circ}$ 3, $2^{\mathrm{a}}$ série, Montemor-o-Novo, Câmara Municipal, 2004, pp. 23-24. Margarida Sobral Neto, Terra e conflito. Região de Coimbra. 1700-1834, Viseu, Palimage, 1997. Teresa Fonseca, Administração senhorial e relações de poder no concelho do Vimieiro (1750-1801), Arraiolos, Câmara Municipal, 1998, pp. 25-26. Id., "Lavre e o seu município entre os domínios senhorial e da coroa", Almansor, no 3, 2a série, Montemor-o-Novo, Câmara Municipal, 2004, pp. 44-45.

3 Implicava apenas as doações dos seguintes direitos: de bens fiscais da coroa, como sesmarias, reguengos, montes maninhos e salinas; das rendas gerais da coroa contidas no respectivo foral; de tributos e impostos sem afectação especial; e de rendas fundiárias, como impostos e jugadas. no plano jurisdicional, o donatário limitava-se a nomear um ouvidor para, em seu nome, julgar em segunda instância os recursos das sentenças dos juízes locais. António Manuel Hespanha, História das instituições. Épocas medieval e moderna, Coimbra, Almedina, 1982, pp. 295-296. Id., As vésperas do Leviathan. Instituições e poder politico. Portugal - séc. XVII, Coimbra, Almedina, 1994, pp. 400-401.

4 Designadamente a apresentação e a confirmação das justiças camarárias, a dada dos ofícios, a isenção de correição régia; e a nomeação de tabeliães, a cobrança das sisas, o padroado régio e o conhecimento dos agravos. António Manuel Hespanha, História das instituições ..., pp. 291-295. Id., As vésperas do Leviathan. Instituições e poder político. Portugal - séc. XVII, Coimbra, Almedina, 1994, pp. 388-401. 
contratos; e eliminaram-se obrigações ilegais, introduzidas abusivamente por senhores laicos e eclesiásticos ${ }^{5}$.

Durante o século XVII, condicionalismos desfavoráveis de ordem externa e interna proporcionaram um agravamento da contestação social em geral, incluindo a de natureza anti-senhorial, esta última também agravada pela intensificação dos abusos e extorsões dos donatários. E depois de várias décadas de aparente acalmia, esta última teria emergido, com uma frequência, amplitude, intensidade, duração e organização inusitadas, entre as últimas décadas de setecentos e a revolução liberal vintista, embora com uma incidência mais significativa na região centro ${ }^{6}$.

Tentaremos, através do exemplo a seguir abordado, contribuir com mais alguns elementos para a discussão deste tema, considerado pelos historiadores que a ele se têm dedicado ainda pouco estudado entre nós.

\section{A vila e termo de Barbacena: breve apresentação histórica}

O concelho de Barbacena teve a sua origem numa herdade com o mesmo nome, conquistada por D. Sancho II e integrada no primitivo termo elvense. Na segunda metade do século XIII, a câmara desta cidade doou-a a Estêvão Anes, chanceler-mor de D. Afonso III, em troca de algumas regalias atribuídas ao concelho. Este construiu aí uma igreja, fixou colonos a quem distribuiu parcelas de terra para arrotear e atribuiu-lhe o primeiro foral, a 17 de Abril de 1273, redigido segundo o modelo do de Santarém. Este senhor registou no mesmo diploma a transferência, para os vassalos, do domínio de uma herdade situada no termo, a Coutada, reservando para si e seus sucessores apenas o oitavo dos frutos que colhessem. Impôs ainda a cada casal o tributo de dois capões, dois alqueires de trigo e dez ovos, a pagar no dia de S. Miguel ${ }^{7}$.

5 Margarida Sobral Neto, “A persistência senhorial”, pp. 171-172.

6 Luís Ferrand de Almeida, "Motins populares no tempo de D. João V. Breves notas e alguns documentos", Revista de História das Ideias, n 6, Coimbra, Faculdade de Letras - Instituto de História e Teoria das Ideias, 1984, pp. 321-343. Hélder Adegar Fonseca, “A propriedade da terra em Portugal.1750-1820: alguns aspectos para uma síntese”, Do Antigo Regime ao Liberalismo. 1750-1850, org. de Fernando Marques da Costa, Francisco Contente Domingues e Nuno Gonçalo Monteiro, Lisboa, Veja, 1989, pp. 214-215. Nuno Gonçalo Monteiro, "Poder senhorial, estatuto nobiliárquico e aristocracia", História de Portugal, (dir. de José Mattoso), vol. 4, "O Antigo Regime”, Lisboa, Estampa, 1993, pp. 360-362. José Tengarrinha, Movimentos populares agrários em Portugal, vol. I - (1751-1807), Lisboa, Europa-América, 1994, pp. 89-166 e vol. II - (1808-1825), pp. 182-196. Margarida Sobral Neto, Terra e conflito..., pp. 312-333.

7 Arquivo Municipal de Elvas (A.M.E.)/ Câmara de Barbacena (C.B.), Livro de registo do foral e de provisões, fls. 1-9v. (cópia de 1815). Sobre o primeiro foral de Barbacena veja-se 
No tempo de D. João I, o donatário João Fernandes Pacheco, reposteiro-mor do rei, tomou o partido de Castela e ausentou-se do reino. Em virtude de tais "maldades e treiçoens" os seus bens foram-lhe confiscados e integrados temporariamente nos da coroa ${ }^{8}$. Mas em 1426 o mesmo monarca doou-os a Martim Afonso de Melo, com a faculdade de "vender, doar e escambar" os ditos bens, "como de couza sua própria” se tratasse. Neles se incluía Barbacena com o seu termo, jurisdições, padroado da igreja da vila, rendas, foros, montados, vinhas, pomares e todos os pertences do anterior senhorio aí existentes ${ }^{9}$.

Durante a jurisdição de D. Afonso Henriques, neto do anterior, D. Manuel I mandou tombar os direitos reais de Barbacena e incluiu-os no novo foral, passado a 15 de Dezembro de $1519^{10}$. Porém, contrariamente à regra geral, omitiu no diploma os direitos senhoriais, por já então ocorrer "comtemda antre o senhorio e os moradores della" cuja solução implicaria "longa demanda e justificação" ${ }^{11}$. O foral salvaguardava a obrigatoriedade de cada uma das partes em litígio cumprir o que sobre tal matéria viesse a ficar decidido nos tribunais régios. Contudo, declarava também não ser "nossa temçam mudar nem alterar há soçessam da dita terra com todos seus direitos da soçessam e herança de como atee quy estam em custume de soçeder, herdar ou partir a dita terra foros ou senhorio della", advertindo implicitamente o povo sobre a natureza patrimonial de Barbacena e as consequentes dificuldades da lei régia para interferir no modo de exploração determinado pelo donatário.

D. Jorge Henriques, bisneto de Martim Afonso, obteve de D. João III vários privilégios: a 18 de Agosto de 1541, a confirmação da jurisdição do concelho, transmissível aos herdeiros, com excepção do padroado da igreja; a 12 de Outubro de 1542, o direito de apresentar tabelião na vila, em sua vida, sempre que o ofício vagasse; e a 3 de Janeiro de 1550 o poder, pelo mesmo período de tempo, de confirmar as justiças da vila. O mesmo soberano autorizou-o ainda a construir o castelo de Barbacena, atribuindo-lhe para o efeito, durante alguns "dois, ou três annos", a terça régia do concelho ${ }^{12}$.

ainda Torre do Tombo (T.T.), Memórias Paroquiais (M.P.), vol. 6, mem. 26 -Barbacena, fls. 157-158. Américo da Costa, Diccionario Chorographico de Portugal Continental e Insular, vol. III, "Barbacena", Vila do Conde, e. a., 1932, pp. 151-153.

8 T.T./ Chancelaria de D. João V, liv ${ }^{0} 14$, fl. 270.

9 Alvará de 1-10-1426, id., id., fl. 270v.

${ }^{10}$ Luís Fernando de Carvalho Dias, Forais Manuelinos. Entre Tejo e Odiana, Fundão, e. a., 1965, "Foral da Terra de Barbacena", p. 158.

${ }^{11}$ T.T./ Gavetas. Gav. a 20, mç. 11, doc. 15 - Processo para o foral de Barbacena., fl 1v.

12 T.T./ Desembargo do Paço (D.P.), Repartição do Alentejo e Algarve (A.-A.), mç. 793, doc. 34. T.T., / M.P., vol. 6, mem. 26 -Barbacena, fls. 157-159. Américo da Costa, Diccionario Chorographico ..., vol. III, pp. 151-156. 
Os antecessores de D. Jorge haviam ampliado abusivamente os poderes legalmente usufruídos, numa prática comum na época, como acima referimos. A carta de doação de 1550 foi-lhe passada na sequência de uma visita do corregedor da comarca de Elvas a Barbacena no ano anterior, durante a qual o magistrado pusera em causa a sua competência para confirmar o juiz da terra, por tal prerrogativa não vir expressa no diploma da doação. Então o visado solicitou a respectiva mercê para si e seus sucessores, invocando a prática dos seus antepassados de confirmação dos juizes, baseados no facto de a vila lhes ter sido doada "com todas as suas jurisdiçoens". A petição foi atendida, embora apenas por sua vida ${ }^{13}$.

D. Jorge faleceu sem herdeiros directos por volta de 1572. A coroa tomou por isso posse da vila, com as suas jurisdições e direitos reais. Mas a 19 de Julho de 1575 arrematou-a, em hasta pública, por 28.500 cruzados, a Diogo de Castro do Rio $^{14}$. A enorme fortuna deste mercador-banqueiro da praça de Lisboa possibilitara-lhe uma colaboração estreita com a coroa que remontava já ao tempo de D. João III. Disponibilizara naus e navios para a segurança das nossas conquistas no Oriente; hospedara gratuitamente fidalgos e embaixadoras estrangeiros; providenciara, em situações de emergência, o abastecimento rápido das armadas reais; emprestara, também graciosamente, elevadas somas, ao monarca e à rainha regente $\mathrm{D}$. Catarina, em tempos de aperto financeiro. Como recompensa de tão relevantes serviços, lograra, em 1558, o hábito da Ordem de Cristo e em 1561 a carta de fidalgo de solar, não obstante a sua condição de cristão-novo ${ }^{15}$.

13 T.T./Chancelaria de D. João V, Comuns, livo 14, fls. 269v.-270. Pela "apresentação", o donatário escolhia as justiças da terra, ficando a sua confirmação reservada para o Desembargo do Paço nas localidades mais importantes ou para o corregedor da comarca nas restantes. Pela "confirmação" a escolha ou eleição competia ao concelho, sendo a ratificação efectuada pelo senhor. Cf. António Manuel Hespanha, As vésperas do Leviathan ..., p. 398.

14 T.T./M.P., vol. 6, mem. 26 -Barbacena, fls. 158-159. Américo da Costa, Diccionario Chorographico ..., p. 156. Há uma ligeira discrepância no valor da arrematação, efectuada, segundo Américo da Costa, por 28.000 cruzados.

${ }^{15}$ João Cordeiro Pereira, "A estrutura social e o seu devir", Nova História de Portugal, coord. de Joel Serrão e Oliveira Marques, vol. V, "Portugal do Renascimento à Crise Dinástica", Lisboa, Presença, 1998, pp. 312-315. A carta de fidalgo de solar conferiu a Diogo de Castro e a seu irmão Luís de Castro o apelido "do Rio", nome de uma sua quinta em Sacavém situada junto do rio Trancão (id., id., p. 314), onde viriam a nascer alguns dos senhores de Barbacena, sucessores de Diogo de Castro (Cf. T.T./Mordomias da Casa Real (M.C.R.), liv ${ }^{\circ}$ 1, fl. 210. No século seguinte, em virtude da aliança matrimonial com uma família da antiga nobreza, os seus sucessores acrescentariam os apelidos de Furtado de Mendonça. Cf. João Cordeiro Pereira, "A estrutura social e o seu devir", p. 315. Afonso Zúquete, Nobreza de Portugal e do Brasil, vol. 2, "Barbacena (Viscondes de)", Lisboa, Enciclopédia, 1961, p. 171. Augusto Soares 
A venda de senhorios constituiu um fenómeno raro entre nós, contrariamente ao ocorrido em Espanha na mesma época e sobretudo na primeira metade do século XVII ${ }^{16}$. Mas neste caso concreto a transacção é compreensível: a localidade, apesar de curtos períodos de integração no património da coroa, havia sido a maior parte do tempo propriedade plena de privados; além disso a alienação proporcionou um importante ingresso para um erário régio em situação particularmente difícil. Contudo, a condição de bem patrimonial reforçava o poder dos donatários e favorecia as suas práticas arbitrárias sobre os moradores e a instituição municipal, afectando o relacionamento entre ambas as partes e fazendo despoletar a onda contestatária que motivou este trabalho.

$\mathrm{O}$ argentário comprador legou a vila ao filho, Martim de Castro do Rio, com a determinação de a integrar num morgadio, a constituir ainda com outros bens. E este último obteve, por alvará de 5 de Junho de 1582, a jurisdição e os direitos reais de Barbacena, retidos na posse da coroa desde a morte de D. Jorge Henriques ${ }^{17}$.

A doação, embora inicialmente atribuída por uma vida, foi ainda nesse ano ampliada a favor do primogénito de Martim de Castro, Luís de Castro do Rio ${ }^{18}$. Mas em 1612 Martim de Castro procurou ampliar a jurisdição genérica que lhe havia sido outorgada, solicitando provisão régia para possuir as prerrogativas de que D. Jorge Henriques "sempre estivera de posse", embora por provisões "que se nam achão por serem de muito tempo e nam andarem incorporadas na sua doação. Eram elas: "todas as jurisdiçoens da villa e se chamar senhor dela e a todos os officiaes se chamarem por elle e de o seu ouvidor confirmar e apurar as eleiçoens dos juizes ordinários e de todas as apellaçoens e agravos hirem ao seu ouvidor"; e ainda dar todos os ofícios de escrivão do judicial e notas, dos órfãos, da câmara e da almotaçaria, bem como a vara de alcaide, sempre que vagassem ${ }^{19}$.

Os oficiais da chancelaria régia não encontraram, como seria de esperar, outras doações além das que acima referimos. Assim, a concessão a Martim de Castro do Rio compreendeu as seguintes prerrogativas: a jurisdição e os direitos reais excepto o padroado da igreja da vila, por D. Jorge o ter tido apenas em sua

d'Azevedo Barbosa de Pinho Leal, Portugal Antigo e Moderno, Lisboa, Mattos Moreira e Companhia, 1874, vol. I, "Barbacena”, p. 320.

${ }^{16}$ António Manuel Hespanha, História das instituições ..., pp. 298-299. Id., As vésperas do Leviathan ..., p. 416. Hélder Adegar Fonseca, “A propriedade da terra em Portugal. 1750-1820", pp. 225-226.

\footnotetext{
${ }^{17}$ Américo da Costa, Diccionario Chorographico ..., vol. III, p. 157.

${ }^{18}$ Por alvará de 30-8-1582. T.T./Chancelaria de D. João V, Comuns, livo 14, fl. 269v.

${ }^{19}$ Id., id., fl. 272.
} 
vida; o apuramento e a confirmação, por si ou pelo seu ouvidor, das eleições dos juízes e demais eleitos locais; e a apresentação dos ofícios vagos da vila, mas não a sua dada, excluída pela cláusula "se não chamarão por elle"20. Foram ainda recusados os direitos de apelação e de agravo, em virtude da sua omissão no texto do diploma ${ }^{21}$.

Além destas prerrogativas, Martim de Castro ainda obteve, após prolongada demanda, a propriedade plena do castelo da vila, não obstante a sua localização fronteiriça e a sua construção a expensas régias ${ }^{22}$.

As doações efectuadas a Martim de Castro do Rio foram, nos mesmos termos, transmitidas aos seus sucessores ${ }^{23}$.

Um seu descendente, Afonso Furtado de Castro do Rio de Mendonça, foi agraciado com o título de $1^{\mathrm{o}}$ visconde de Barbacena, por carta régia de 19 de Dezembro de 1661. O título, que continuou nos seus descendentes, foi-lhe atribuído em virtude dos relevantes serviços militares prestados durante a Guerra da Restauração ${ }^{24}$ e ainda como governador e capitão-general do Brasil ${ }^{25}$.

O concelho de Barbacena, com uma área de 29,8 km2, incluía-se entre os mais pequenos do reino ${ }^{26}$. Possuía uma única paróquia, sedeada dentro da vila. Sendo a igreja, como vimos, padroado régio, o prior e o beneficiado eram de apresentação da coroa. Fora da sede concelhia não possuía qualquer aldeia ou lugar, apenas alguns montes habitados por lavradores. Não tinha conventos de

${ }^{20} I d$., id., fls. 272-272v. Enquanto pela "apresentação" o donatário apenas escolhia o oficial, pela "dada" podia passar a carta do ofício e entregar o regimento. Em ambos os casos o oficial devia previamente submeter-se, com aprovação, a um exame no Desembargo do Paço. Cf. António Manuel Hespanha, As vésperas do Leviathan ..., p. 399.

${ }^{21}$ Passado a 15 -3-1612. Cf. T.T./Chancelaria de D. João V, Comuns, liv ${ }^{\circ} 14$, fl. 272 v. A doação das apelações implicava o carácter definitivo do seu julgamento. A dos agravos significava o conhecimento dos agravos crimes por parte dos ouvidores, em lugar dos corregedores da respectiva comarca. Cf. António Manuel Hespanha, As vésperas do Leviathan ..., pp. 395-396; id., História das instituições ..., pp. 300-301. Sobre a distinção entre apelo e agravo, veja-se Marcelo Caetano, História do direito português (1140-1495), Lisboa, Verbo, 1985, pp. 585-586.

${ }^{22}$ Américo da Costa, Diccionario Chorographico ..., vol. III, p. 157-159.

${ }^{23}$ T.T./Chancelaria de D. João V, Comuns, liv ${ }^{\circ} 14$, fls. 267-269v; e 272v.-275.

${ }^{24}$ Id., id., fls. 268-269.

${ }^{25}$ Afonso Zúquete, Nobreza de Portugal e do Brasil, vol. 2, "Barbacena (Viscondes de)", p. 171.

${ }^{26} \mathrm{Na}$ província do Minho, onde estas unidades territoriais atingiam as menores dimensões de todo o reino, a sua área média era de $49 \mathrm{Km} 2$. A média nacional situava-se pouco acima dos $100 \mathrm{Km} 2$; e a do Alentejo em pouco mais de $230 \mathrm{Km} 2$. Cf. Luís Vidigal, "Poderes locais em Portugal nos inícios do século XIX - elementos para a caracterização das instituições de poder central periférico e das instâncias concelhias", Ler História, nº 16, Lisboa, 1989, pp. 52 e 59. 
frades ou freiras. Possuía, como a generalidade das sedes concelhias alentejanas, o seu celeiro comum, para auxílio dos pequenos lavradores e seareiros. A irmandade da Misericórdia, constituída em 1620, administrava um pequeno hospital ${ }^{27}$. Por alvará de 15 de Junho de 1703, D. Pedro II colocou a Santa Casa sob protecção régia; tal condição permitiu-lhe obter indultos e privilégios e adoptar o Compromisso da Misericórdia de Lisboa ${ }^{28}$.

De acordo com os dados disponíveis, Barbacena e o seu termo teriam, em 1527, apenas 64 fogos ${ }^{29}$. O seu número, acompanhando a tendência nacional e europeia, cresceu consideravelmente ao longo desta centúria, atingindo os 140 em $1660^{30}$; o ritmo de crescimento teria porém abrandado nas décadas seguintes, pois contava 150 vizinhos em $1708^{31}$. Durante as duas primeiras décadas de setecentos, mais uma vez num processo paralelo ao ocorrido em todo o reino, verificou-se, em 1735, uma descida para $140 \operatorname{fogos}^{32}$. A recuperação generalizada a partir da terceira década deste século também se fez aqui sentir, com 150 fogos em $1748^{33}, 257 \mathrm{em} 1757^{34}$ e cerca de $300 \mathrm{em} 1801^{35}$.

Situado em região fértil, o termo de Barbacena, apesar de exíguo, produzia bastante trigo, centeio e cevada, ao ponto de ter constituído, durante a guerra da Restauração, uma das principais fontes do abastecimento cerealífero da praça militar de Elvas ${ }^{36}$. Nos seus pastos criavam-se carneiros, ovelhas, cabras, porcos e bovinos. E nos montados abundava a caça, principalmente lebres e perdizes ${ }^{37}$.

${ }^{27}$ T.T./M.P., vol. 6, mem. 26 -Barbacena, fls. 160-164.

${ }^{28}$ I., Chancelaria de D. Pedro II, Comuns, liv ${ }^{\circ} 55$, fl. 17v.-18.

${ }^{29}$ Luís Fernando de Carvalho Dias, Forais Manuelinos. Entre Tejo e Odiana ..., p. 173

${ }^{30}$ Augusto Soares d'Azevedo Barbosa de Pinho Leal, Portugal Antigo e Moderno, vol. I, "Barbacena", p. 319.

${ }^{31}$ António Carvalho da Costa, Corografia Portugueza e Descripçam Topográfica do Famoso Reyno de Portugal, Lisboa, Na Officina de Valentim da Costa Deslandes, 1708, tomo II, p. 552.

${ }^{32}$ T.T./M.P., vol. 6, mem. 26 -Barbacena, fl. 160.

${ }^{33}$ Id., id.

${ }^{34}$ Augusto Soares d'Azevedo Barbosa de Pinho Leal, Portugal Antigo e Moderno ..., vol. I, p. 319. Considerámos "fogo" e "vizinho" como equivalentes, designando unidades familiares, de acordo com José Vicente Serrão, "O quadro humano" História de Portugal, dir. de José Mattoso, vol. IV, “O Antigo Regime”, Lisboa, Estampa, 1993, p. 49.

${ }_{35}$ A.M.E./ C.B., Livro de registo do foral e de provisões, fl. 10.

${ }^{36}$ P. M. Laranjo Coelho (pub. e pref.), Cartas dos governadores da província do Alentejo a el-rei D. Afonso VI, vol. III, Lisboa, Academia Portuguesa de História, 1940, carta do Conde de Atouguia de 9-4-1660, pp. 24-26.

37 T.T./M.P., vol. 6, mem. 26 -Barbacena, fl. 160. 
O elenco camarário era composto por dois juízes ordinários, três vereadores e um procurador do povo. Os juízes, embora leigos em matéria jurídica, despachavam com o apoio de um assessor letrado, como sucedia então em mais municípios de idêntica categoria institucional. Devido ao número reduzido de moradores, as funções de escrivão da câmara, do judicial e notas, dos órfãos e da almotaçaria concentravam-se no mesmo oficial ${ }^{38}$.

O concelho recebia, em princípio anualmente, a visita de inspecção não só do provedor como também do corregedor da comarca de Elvas, pois apesar de constituir um domínio senhorial nunca esteve isenta de correição régia, privilégio apenas atribuído aos grandes senhorios.

Como todas as terras da fronteira alentejana, Barbacena foi particularmente sacrificada durante as guerras com o país vizinho e durante a primeira invasão francesa. Em 1648, sofreu por duas vezes a ocupação castelhana ${ }^{39}$, não sem antes ter oferecido "muitas horas" de resistência ${ }^{40}$, certamente possível devido às obras de fortificação no castelo, empreendidas pelo $1^{\circ}$ visconde da vila $\mathrm{e}$ general de cavalaria do exército do Alentejo ${ }^{41}$. Os ocupantes chegaram a queimar a vila ${ }^{42}$, como praticaram em outras pequenas localidades da região. Em 1801, o exército espanhol devastou "aquella Povoação, queimando os Cartórios da Camera, e judicial, obrigando a emigrarem mais de sincoenta famílias "43. E em 1807 viram-se obrigados a travar "extraordinárias disputas" com os franceses e sofreram a passagem e o aquartelamento do exército português e britânico. Estes acontecimentos esgotaram "não somente todos os rendimentos do Concelho mas athé dos pobres Moradores, a maior parte dos quais apenas possuião huma pequena abitação foreira ao Donatário" "44.

O concelho de Barbacena foi extinto por decreto de 6 de Novembro de 1836 e integrado no de Elvas.

${ }^{38}$ T.T./Chancelaria de D. João V, Comuns, livº 122, fl. 93v., provisão de 12-4-1734.

39 A primeira ocorreu na Primavera de 1648, tendo o exército ocupante sido escorraçado da vila pelo próprio governador das Armas da província, Martim Afonso de Melo. Cf. P. M. Laranjo Coelho (pub. e pref.), Cartas dos governadores da província do Alentejo a el-rei D. JoãoIV, vol. I, Lisboa, Academia Portuguesa de História, 1940, carta do governador Martim Afonso de Melo, de 15-6-1648, pp. 278-279. A segunda, em Outubro do mesmo ano, coincidiu com o início do cerco a Elvas. Cf. Conde da Ericeira, História de Portugal Restaurado, Porto Livraria Civilização, 1945, vol. 3, p. 150.

${ }^{40}$ Conde da Ericeira, História de Portugal Restaurado, vol. 3, p. 150.

${ }^{41}$ Américo da Costa, Diccionario Chorographico ..., p. 159. T.T./Chancelaria de D. João V, Comuns, liv 14 , fl. 268.

${ }^{42}$ T.T./Chancelaria de D. João V, Comuns, liv $^{\mathrm{o}} 14$, fl. 268v.

${ }^{43}$ A.M.E./ C.B., Livro de registo do foral e de provisões, fl. 10.

${ }^{44}$ Id., id., fl. $10 \mathrm{v}$. 


\section{Os conflitos da câmara e do povo de Barbacena com os donatários}

Barbacena viveu num conflito permanente com os seus donatários, ora latente ora explícito, assumindo por vezes expressões violentas, aparentemente mais frequentes, vigorosas e prolongadas durante o século XVIII.

Comprova-o, como vimos, o próprio texto do processo preparatório do foral. Pelas inquirições prévias efectuadas na vila, constatara-se que o povo, baseado nos direitos consignados no primeiro foral, reivindicava o pagamento do oitavo das colheitas, quando o senhor os agravava com "o seysto e quinto e quarto". Mas havia ainda divergências "nos outros direitos da terra", incluindo "foros e pensoões" ${ }^{45}$.

Em 1771, o $5^{\circ}$ visconde de Barbacena ${ }^{46}$, em representação dirigida ao Desembargo do Paço, informava que desde o estabelecimento da vila até ao seu tempo "tinhão sido tantos, e tão grandes os desconcertos dos seus habitantes, que lhe não tinha sido possivel possuir, e perceber tranquilamente o que indubitavelmente lhe pertencia" ${ }^{\prime 4}$.

No caso da dúvida sobre a confirmação das justiças surgida em 1549, não devemos excluir a hipótese de ter sido inicialmente levantada pela própria gente da governança local e de o corregedor ter agido por sua sugestão ou a seu pedido. De outro modo, porque não contestou o magistrado as demais prerrogativas de legalidade igualmente duvidosa, exercidas pelo donatário? Com efeito, a confirmação dos eleitos, a ser praticada com rigor, acabaria por transformar os mais próximos representantes do poder régio junto da comunidade em meros agentes do poder senhorial. Por isso, a questão pode ter sido, muito provavelmente, uma acção de resistência implícita da instituição municipal.

As divergências, porém, adquirem contornos mais explícitos a partir de 1683. Neste ano, o $2^{\circ}$ visconde Jorge Furtado de Mendonça, obteve provisão régia para tombar e demarcar as terras de Barbacena ${ }^{48}$. Mas antes de proceder à demarcação, o procurador do titular registou no tombo "muitos direitos, regalias, jurisdesoens e fazendas" inexistentes no foral de 1519 e no documento de arrematação de 1575, sem apresentar qualquer título justificativo. Tal introdução,

${ }^{45}$ T.T./Gavetas, gav ${ }^{\mathrm{a}} 20$, mç. 11 , doc. 15 - Processo para o foral de Barbacena, fl 1v.

${ }^{46}$ Francisco Vicente Xavier Furtado de Castro do Rio e Mendonça (1720-1790). Veja-se sobre este titular Américo da Costa, Diccionario Chorographico ..., p. 162. Afonso Zúquete, Nobreza de Portugal e do Brasil, vol. 2, "Barbacena (Viscondes de)", p. 171.

${ }^{47}$ Id., D.P. A.-A., mç. 793, doc. 35.

${ }^{48}$ Sobre a importância atribuída no século XVII pelos senhores à demarcação das suas terras, com o objectivo de as controlarem e reiterarem os seus direitos, veja-se Margarida Sobral Neto, Terra e conflito ..., pp. 39-56. 
apesar de abusiva e prejudicial ao povo, à câmara e à coroa, havia sido ratificada pelos oficiais camarários da época por serem, segundo os seus sucessores do ano de 1771, "pesoas rústicas" que por esse facto "reconhecerião, consentirião e asignarião quanto se lhe propuzese", mais ainda apoiados pelo corregedor, que nessa ocasião "bem mostrou o seu excesso a favor do Donatário"49.

A maior parte do termo de Barbacena era constituída por pastos baldios, desde sempre usufruídos pelo povo. Porém, pelo menos a partir da elaboração do referido tombo, os donatários passaram a vender as pastagens por sua conta ${ }^{50}$. Em consequência de tal medida, os moradores tiveram de se desfazer de grande parte do gado; e a câmara viu consideravelmente diminuídas as suas receitas, provenientes em boa parte das coimas relativas ao dito gado ${ }^{51}$.

Assim usurpados os baldios, apenas restava aos moradores e ao município a Coutada doada por Estêvão Anes, que também sempre estivera na sua posse. Porém, Jorge Furtado de Mendonça, invocando o seu direito de proprietário, reduzira a carvão toda a lenha desta pequena herdade. Em consequência do desbaste, tanto ele como os seus filhos, o $3^{\circ}$ e o $4^{\circ}$ viscondes, Afonso Francisco Furtado de Mendonça e Luís Xavier Furtado de Mendonça ${ }^{52}$, desinteressaram-se pela Coutada durante várias décadas e os moradores retomaram o costume ancestral de aí introduzir o seu gado. Porém, quando a produtividade do terreno recomeçou a ser lucrativa, este último titular "mandou o ouvidor lançar pregão publico para que ninguem se atrevece a tirar fruto algum". Não obstante, em Novembro de 1729, "entrou o povo em tom de motim e a disfrutou", repetindo o procedimento em $1730^{53}$.

Nestas acções os populares foram apoiados e até instigados pelos oficiais camarários. O donatário acusava estes últimos de mandarem "publicar das janellas da dita Câmara, que quem quizeçe semease as terras da dita coutada" e de terem ainda vendido as pastagens desta defesa sem lhe terem requerido a

${ }^{49} I d$., id., mç. 793, doc. 36, representação do povo de Barbacena. 1771.

${ }^{50}$ A apropriação dos baldios pelos poderosos locais era, como acima referimos, uma prática muito frequente. O alvará de 23 de Julho de 1766, regulamentador do regime de aforamento dos baldios e bens dos concelhos, teve como principal objectivo atalhar o usufruto indevido dessas terras e assim aumentar as rendas dos concelhos e as terças régias.

${ }^{51}$ T.T./D.P. A.-A., mç. 793, doc. 36, representação do povo de Barbacena.

${ }^{52}$ Desconhecemos a data da poda da coutada, mas foi efectuada antes de 1708, data da morte do $2^{\circ}$ visconde. O seu primogénito, Afonso Francisco, seguiu a vida religiosa em 1713 , renunciando em seu irmão, Luís Xavier, a posse do morgadio, direitos reais e jurisdição de Barbacena. Cf. T.T./ Chancelaria de D. João V, Comuns, livº 14, fls. 267-267v. Américo da Costa, Diccionario Chorographico ..., pp. 161-162. Afonso Zúquete, Nobreza de Portugal e do Brasil, vol. 2, "Barbacena (Viscondes de)", p. 171.

${ }^{53}$ T.T./D.P. A.-A., mç. 793, doc. 36, representação do povo de Barbacena. 1771. 
devida licença. O clima de contestação chegara ao ponto de o fidalgo considerar impossível entrar na vila "sem notório perigo", para a sua vida e a do seu ouvidor. Solicitou, por isso, a intervenção régia. E sugeriu que o magistrado nomeado para tirar devassa entrasse em Barbacena "com a maior cautella, $e$ segredo", seguido de "huma Companhia de Cavallos" e remetesse "em costodia para parte segura" os principais amotinadores, a saber: o beneficiado Manuel da Ponte, em sua oponião a "Cabeça prencipal da Sublevaçam"; o segundo juiz ordinário, Manuel Gomes Velho; os vereadores António Marques, António Gonçalves Serrano e o procurador do concelho António Sardinha de Brissos; e ainda os procuradores que redigiram a queixa contra ele, além de "Outros muntos" 54 .

Em consequência da petição de Luís Xavier de Mendonça, o corregedor de Elvas foi enviado à vila para tirar devassa "do motim e sublevação". O padre Manuel da Ponte foi mandado retirar para quarenta léguas de distância; os restantes cabecilhas foram remetidos à cadeia da sede da comarca; e a coutada foi devolvida ao donatário ${ }^{55}$.

A decisão desfavorável e a condenação dos agitadores não demoveram a câmara nem o povo. Comprova-o uma provisão régia de 21 de Julho de 1753 , pela qual a edilidade era autorizada a lançar no cabeção da vila 200.000 reis. A receita destinava-se à liquidação de algumas dívidas contraídas pelo concelho, para custear uma demanda que traziam há "vinte annos" contra o donatário, "para effeito de se livrarem a pagar lhe muitos tributos, que contra a forma do seu Fural lhes está levando, e pertendia levar."

Embora sem desistir da exploração da coutada, como veremos adiante, as autoridades locais e os moradores centraram a acção reivindicativa em outro ponto de divergência com donatário, este, como vimos, já com vários séculos de existência: o agravamento dos encargos tributários, relativamente ao estabelecido no primeiro foral da vila, o único onde vinham estabelecidos os direitos senhoriais, como igualmente foi mencionado.

No ano seguinte, porém, o $4^{\circ}$ visconde requereu a anulação da provisão. Alegava que o corregedor informante da petição popular auscultara apenas os membros do senado camarário e mais algumas pessoas interessadas em atentar contra os seus direitos senhoriais. O Desembargo do Paço ordenou então uma averiguação mais cuidada, pela qual se apurou serem apenas 28 os interessados na cobrança da finta, contra 97 que a contestavam. A primeira lista, a única

\footnotetext{
${ }^{54}$ Id., id., mç. 793, doc. 34 .

55 Id., id., mç. 793, doc. 34, despacho de 6-8-1731.

${ }^{56}$ Id., id., mç. 793, doc. 34. Id., Chancelaria de D. José, Comuns, livo 45, fl. 132v.
} 
que conhecemos, era encabeçada pelos três vereadores então em exercício; seguiam-se dez membros da pequena nobreza local e por fim doze homens do povo. Em face de tais resultados, o tribunal régio recuou na sua decisão. Anulou a provisão anterior e ordenou, por nova determinação, que se fintassem apenas as 28 pessoas constantes do rol de apoio ${ }^{57}$.

A demanda prosseguiu, apesar do aparente desinteresse da maioria dos moradores, porventura originado no receio de represálias por parte do donatário ou dos seus agentes na vila; e ainda decorria em 1758, como informava, na memória paroquial, o prior Francisco da Costa Matos. Nesta data, corria também nos tribunais outra acção, respeitante ao velho litígio sobre o domínio dos pastos baldios; e uma terceira "sobre outras muitas regalias" entretanto retiradas, incluindo, uma vez mais, a questão do usufruto da Coutada e a contestação da obrigatoriedade de utilização do forno senhorial. E sobre estas duas o pároco informava que já havia sido proferida "há mais de vinte annos" uma sentença, da qual a câmara e o povo tinham recorrido, por lhes ter sido desfavorável ${ }^{58}$.

Tal como havia sucedido, quase três décadas atrás, com o beneficiado Manuel da Ponte, o prior manifestava uma posição favorável ao município e aos moradores, sem assumir embora o papel interventivo do primeiro religioso. Acusava o $4^{\circ}$ visconde de "não consentir (...) na villa mais forno que o seu" e de desenvolver esforços no sentido de arrastar o mais possível a questão nos tribunais. Levantava, implicitamente, a suspeita do seu envolvimento na ocultação de provas documentais eventualmente favoráveis à causa popular: "E para maior confusão e desordem se retirou do Cartório do escrivão da Câmara o seu foral (...) há poucos annos", não se podendo por isso dar "o de Deos a Deos nem o de Sesar a Sesar" 59 .

Segundo o mesmo sacerdote, os camaristas teriam aproveitado a visita do rei D. José a Vila Viçosa, para lhe pedirem a mercê de obrigar o donatário a repor o foral no seu devido lugar ${ }^{60}$. Mas quando a petição escrita subiu à Secretaria de Estado do Reino os seus oficiais, em lugar de lhe darem execução, anexaram-na à causa principal. E por isso continuava "a gemer o Povo e continuará enquanto Vossa Magestade lhe não puser os olhos da sua clemência, mandando deferir lhe como for de justiça" 61 .

57 T.T./D.P. A.-A., mç. 793, doc. 34, provisão de 4-7-1755.

${ }^{58}$ T.T./M.P., vol. 6, mem. 26 -Barbacena, fl. 167 e 169.

${ }^{59}$ Id., id., fl. 169.

${ }^{60} \mathrm{O}$ rei D. José esteve em Vila Viçosa entre 28 de Abril e 28 de Maio de 1751. Cf. Teresa Fonseca (Estudo e transcrição), Triste e alegre cidade de Évora. Testemunho de um anónimo do século XVIII, Évora, Câmara Municipal, 2001, pp. 36-37.

${ }^{61}$ T.T./M.P., vol. 6, mem. 26 -Barbacena, fl. 167 e 169. 
O ambiente de tensão parece ter-se acentuado com a transmissão do senhorio ao $5^{\circ}$ visconde, a avaliar pela representação do povo de Barbacena, dirigida ao Desembargo do Paço em $1771^{62}$.

Em 1768, em consequência de uma sentença a seu favor obtida no juízo da coroa, Francisco Furtado de Mendonça começara a vender anualmente os pastos dos baldios, privando a comunidade da sua "antiquissima posse". Alguns lavradores, por não terem onde apascentar o gado, mudaram-se para outros concelhos. E a maior parte dos que ficaram passaram a explorar terras no termo de Elvas, deixando as de Barbacena por cultivar.

Desta maneira, apenas passou a restar a Coutada para sustento do gado do povo. Mas como a câmara costumava vender o pasto desta defesa "alguns mezes no anno para as necessárias despezas do concelho", se a disponibilizasse aos moradores ficava sem meios de subsistência e assim impedida de "defender a jurisdição real”, como era seu dever. Porém, para agravar a situação, o donatário tentava "uzurpar" esta herdade de ancestral exploração comunitária e deste modo reduzir a povoação ao "seu ultimo fim". Para o efeito, baseado numa provisão que atribuíra a seu pai a administração provisória deste terreno comunitário até à decisão de algumas causas pendentes relativas à sua posse, Francisco Furtado obtivera, em 1768, outra provisão que impedia, "contra o costume antiquíssimo", a câmara de a coutar e descoutar, sem sua autorização.

Mas nesse ano, como o senhorio a não tivesse mandado descoutar em tempo conveniente, e também por se encontrar "carregada com o gado do povo", ninguém se mostrara interessado na sua compra. Por conseguinte "ficou o concelho empenhado" em 63.585 reis e a terça régia baixou para os 14.000 reis, quando nos anos anteriores havia sido "muito mais avultada". Em 1769, embora o gado do povo aí tivesse comido, a câmara conseguiu vender alguns pastos, por 100.000 reis. Porém, como o donatário também passara a cobrar o oitavo do seu rendimento, tanto a receita camarária como a terça régia tinham sofrido prejuízo. Ora como o foral de criação da vila determinava que relativamente aos rendimentos dos quais se não determinava expressamente o pagamento do oitavo apenas o deviam pagar se também pagassem o dízimo, a Coutada, como não o pagava, também devia, na opinião do povo, estar isenta do oitavo.

O marechal de campo era ainda acusado de "dezigualdade" na repartição das terras de cultura, por destinar "as boas aos seos validos, e as inferiores a mais do povo”. Este, devido à sua baixa produtividade, preferia deixá-las incultas. Não obstante, o donatário, baseado numa das declarações introduzidas no tombo de 1683, exigia, do mesmo modo, o pagamento do oitavo.

${ }^{62}$ T.T./D.P. A.-A., mç. 793, doc. 36, representação do povo de Barbacena de 1771. 
Apontavam-lhe ainda o aforamento indevido de uns chãos situados perto do rossio da vila e de todas as vinhas e hortas dos coutos quando, pelo foral antigo, tais propriedades estavam apenas obrigadas ao oitavo. Para as aforar, o senhorio expulsara os seus antigos donos. Mas também não hesitava em retirá-las aos novos foreiros quando "por pobreza" deixavam de lhe pagar os "indevidos foros".

Denunciavam-lhe a apropriação abusiva de uma horta e de uma pequena herdade, ambas pertença da coroa, que por isso não tinham sido transferidas no auto de arrematação nem constavam dos títulos de compra e de posse. E contestavam a imposição de foro a cada morada de casas, bem como a cobrança de laudémio decorrente da sua venda, quando o instituidor de Barbacena apenas impusera, a cada casal, a pensão, já acima mencionada, de dois alqueires de trigo, dois capões e dez ovos. Por último alegavam que o donatário, tal como os seus antecessores, justificava todas estas "uzurpaçoens" com sentenças que tinha obtido, fundamentadas nas declarações introduzidas no tombo de 1683. E consideravam que o pedido do alvará régio de demarcação das terras de Barbacena havia constituído um mero pretexto para o $2^{\circ}$ visconde registar direitos que nunca lhe haviam sido atribuídos ${ }^{63}$.

$\mathrm{Na}$ sequência da representação popular, Francisco Furtado de Mendonça dirigiu, nesse ano, uma petição ao mesmo tribunal régio ${ }^{64}$. Começava por expor a "continua perturbação" em que vivia, atribuída a "huns indivíduos orgulhozos". As sentenças que alcançava a seu favor no juízo da coroa nunca eram "bastantes para o seu socego" e em sua opinião nunca o seriam, enquanto habitassem naquela vila "os espíritos trafegozos" que o inquietavam, "porque extincto hum projecto" suscitavam logo outro. Entre tais "génios inquietos" destacava João Antunes Borralho e Filipe Pinheiro Valente, juízes ordinários da vila; e António Cordeiro, procurador do concelho. Aos três, atribuía a autoria da representação popular que acabámos de referir ${ }^{65}$.

De acordo com as sentenças alcançadas a seu favor em 1768, respeitantes a uma causa "disputada por tempo de trinta annos", o povo devia pagar-lhe uma multa por contravenção dos direitos senhoriais. $\mathrm{O} 5^{\circ}$ visconde comunicou a João Borralho que perdoaria a pena ao povo, se este lhe pedisse perdão. Porém, Borralho recusou-se a comunicar tal sugestão aos seus conterrâneos e a multa acabou por ser repartida por todos, "pagando o pobre como o abonado".

\footnotetext{
${ }^{63} I d$, id.

${ }^{64}$ Id., id., mç. 793, doc. 34.

${ }^{65}$ Id., id.
} 
Alguns, quando souberam da intenção do seu senhor, "pediram-lhe perdão" e foram isentos ${ }^{66}$.

O grupo liderado por Antunes Borralho formulara nova queixa ao soberano em 1769. Mas como foram desatendidos, este magistrado local "repetio a inquietação não só ao suplicante, mas também a maior parte do Povo rústico e ignorante persuadindo o que parte do que se concedeo ao suplicante (...) se lhe havia de restituir, e sacando de outra contribuição, se apresentou" na corte. Daí, convencera os moradores a enviarem-lhe "paios, chourissos, e queijos para certos prezentes", indispensáveis ao bom sucesso das suas diligências. Pediu também dinheiro, para gastos pessoais e do processo, que foi obtido através da venda da folhagem das vinhas de "muitos moradores". Porém, nada adiantara com a repetição da queixa ${ }^{67}$.

Entre os quatro homens que "andarão pedindo pelo Povo" os enchidos, o donatário destacava um seu antigo procurador e feitor, João Gonçalves Vargas. Este, durante três anos, exercera a função "tão mal que a converteo toda em seu prejuizo asociando se aos que se armão contra" ele, "por cujo motivo o despedio" 68 .

Em face do exposto, pedia, para João Antunes Borralho, como "primeiro móvel de todas as inquietaçoins", a prisão e deportação para "hum dos lugares ultramarinos", pois enquanto estivesse no reino, nem ele, suplicante, nem a maior parte dos moradores viveriam tranquilos. Para João Gonçalves Vergas e para "os mais que andarão pedindo paios, chouriços, e a folhada das vinhas", requeria o degredo para uma distância de quarenta léguas de Barbacena ${ }^{69}$.

O Desembargo do Paço requereu, como habitualmente, o parecer do corregedor da comarca, João da Rocha Dantas e Mendonça, enviado pelo magistrado em Setembro do mesmo ano ${ }^{70}$. Baseado na doação de D. João I, no título de compra da vila e seu termo, no tombo de 1683 e nas provisões, resoluções e sentenças alcançadas pelos donatários, o ministro da comarca refutou as queixas do povo. Argumentava que o tombo seiscentista não alterara a substância do foral de 1273. Considerava "todo o território" de Barbacena como património privado do visconde. Acusava os moradores de terem ido "comer o alheio" ao ocuparem os baldios. Criticava-lhes o facto de transportarem para a Coutada não apenas o gado indispensável à agricultura, mas também

\footnotetext{
${ }^{66} I d ., i d$.

${ }^{67}$ Id., id., mç 793, doc. 33.

${ }^{68} \mathrm{Id}$., id.

${ }^{69}$ Id., id., mç. 793, doc. 34

${ }^{70} I d$., id., mç. 793, doc. 36, parecer de 6-9-1771.
} 
o que criavam para vender. Reputava de ilegal a acção da câmara de coutar e descoutar esta defesa, sem licença do seu proprietário. E punha em causa a alegada falta de recursos do município, pois as suas receitas, além do rendimento dos pastos, incluíam as coimas e as rendas do campo, da vila, das medidas e das calçadas.

Em conclusão, parecia-lhe supérflua a petição dos moradores, por levantarem uma questão decidida "repetidas vezes nos Tribunaes competentes"; e por isso devia ser escusada. E concordava que se desse “alguma Providencia” para fazer “aquelles orgulhozos individuos" respeitarem as resoluções régias e as sentenças dos tribunais superiores e deixarem de inquietar "quotidianamente os Magistrados com as mesmas questoens, queixas e pleitos, já propostos, dicididos e terminados ${ }^{\prime 71}$.

Em Dezembro, o seu substituto, António Procópio da Silva Pina, propunha o degredo para Borralho e Vergas, mas apenas seis meses de prisão para o procurador do concelho e mais cinco agitadores ${ }^{72}$.

A decisão régia não se fez esperar. Em Janeiro de 1772, os desembargadores do Paço, embora concordando, no essencial, com a opinião do corregedor Dantas e Mendonça, consideravam os aforamentos “inválidos” por carecerem de provisão régia e do consentimento do sucessor imediato do donatário. Tal facto, porém, não justificava, no seu entender, o comportamento dos moradores. Por isso, ordenaram ao corregedor o envio de João Antunes Borralho e do advogado redactor da representação popular para a prisão do Limoeiro. Borralho ficaria, ainda, impedido de voltar a servir na edilidade como juiz. O ministro da comarca ficava incumbido de convocar a câmara e na presença de todos os seus membros repreender o juiz prevaricador "pella formal desobediência que praticou contra as sentenças alcansadas pelo Donatário”. E devia também advertir a mesma câmara de que não devia "suscitar pontos já competentemente decididos", sob pena de maior castigo ${ }^{73}$.

Porém, nenhum dos acusados pelo donatário foi degredado. João Gonçalves Vergas, que já antes havia sido vereador, foi até eleito juiz ordinário. Durante o exercício deste cargo cimeiro do município, Francisco Furtado moveu-lhe novo processo, "por ser orgulhozo e perturbador do sucego Publico". Em consequência da queixa foi de novo preso em 1774, suspenso do

\footnotetext{
${ }^{71}$ Id., id.

${ }^{72}$ Id., id., mç. 793, doc. 33, carta de 20-12-1771, do juiz de fora de Elvas, servindo de corregedor, António Procópio da Silva Pina.

${ }^{73}$ Id., id., mç. 793, doc. 31, resolução de 10-1-1772.
} 
ofício camarário e considerado "inhabel para este, e outro qualquer Cargo da Republica"'74.

$\mathrm{Na}$ origem da atitude do titular e da condenação do juiz local esteve certamente mais um conflito, porventura de menores dimensões, entre o senhor de Barbacena e os seus subordinados.

Depois de uma década de aparente acalmia, os conflitos ressurgiram com força redobrada. No dia 29 de Outubro de 1785, José António Costa, couteiro do donatário, avistou "varias pessoas (...) assim Homens, como Mulheres, e Rapazes" a invadir a Coutada. Apanharam "toda a Bolota que puderão", sem que o guarda "o podesse impedir, por ser grande o numero das pessoas", não obstante as "muitas instancias que lhes fés para o fim de não querer consentir na apanha (...) por ser em tempo que ahinda não era mandado descoutar". Desta vez, o líder da transgressão popular foi José Parreiras. Quando o couteiro o quis impedir, "Parreiras se levantou contra elle (...) resestindo the e desatendendo o de tal forma que sempre conseguio levar da coutada a bolota que quis" 75 .

Apesar de muitos terem fugido, António da Costa conseguiu reunir uma lista com 34 nomes, 22 dos quais de mulheres, duas delas ainda meninas. Entre os infractores incluíam-se o boticário da vila e um seu filho; José Parreira, acompanhado da mulher; uma cunhada do próprio couteiro; e ainda a mulher de José António da Ponte, um dos acusados de envolvimento na angariação do dinheiro da folhagem das vinhas, destinado a custear a acção movida, em 1770, contra o donatário ${ }^{76}$.

O corregedor José Francisco Xavier Lobo Pessanha mandou prender, apenas por "alguns dias", o "orgulhozo" José Parreira, por não ter encontrado pena estabelecida contra quem invadisse a Coutada e também por lhe parecer "que o medo da prisão" seria suficiente para impedir os transgressores e os seus conterrâneos "de outra vez devassarem tão descaradamente" a defesa ${ }^{77}$.

Porém, Francisco Furtado denunciou ao tribunal régio a "brandura" da pena, do seu ponto de vista insuficiente para coibir os "revoltozos ânimos daquelle Povo". Em face das representações do magistrado e do donatário, a Mesa do Desembargo do Paço determinou a aplicação de uma pena proporcional à

${ }^{74} I d$., id., mç. 793, doc. 31, resoluções de 7-6-1774 e de 24-11-1774.

${ }^{75}$ Id., id., mç. 793, doc. 31, inquéritos de testemunhas de 24-11-1785 e de 16-8-1786.

${ }^{76}$ Id., id., mç. 793, doc. 31, "Relaçam das pessoas que se acharão na coitada da Villa de Barbacena, furtando bolota".

${ }^{77}$ Id., id., mç. 793, doc. 31, carta do corregedor de Elvas, José Francisco Xavier Lobo Pessanha, de 16-8-1786. 
reincidência dos moradores: dois meses de prisão na cadeia da sede da comarca e 6.000 reis de multa, a aplicar em obras públicas no concelho ${ }^{78}$.

O castigo, porém, não logrou, uma vez mais, atalhar a determinação dos populares, que persistiam em introduzir o seu gado na Coutada, antes da data determinada. E enquanto o guarda ia procurar testemunhas, os moradores retiravam os animais, deixando a defesa destruída. Por isso, em 1795, o $6^{\circ}$ visconde ${ }^{79}$ requereu a atribuição de uma "provisão coimeira" ao seu couteiro, que lhe permitisse encoimar os gados no próprio momento da transgressão $0^{80}$.

\section{Notas finais}

O povo e a câmara de Barbacena viveram, pelo menos entre o século $\mathrm{XV}$ e os finais do século XVIII, um relacionamento conflituoso com os seus donatários. Tal clima de tensão prolongou-se, provavelmente, até ao termo do Antigo Regime económico. Comprova-o uma petição do $2^{\circ}$ conde $^{81}$, dirigida em 1830 ao Desembargo do Paço, na qual afirmava possuir naquela terra "muitos rendeiros os quaes percizava frequentes vezes demandar em Juizo para lhe pagarem o que devião assim como tinha por vezes Demandas e dependências Judeciaes com outros moradores da mesma Villa" ${ }^{\text {"2. }}$.

As dificuldades de convivência possuíam uma origem idêntica às dos movimentos da mesma natureza ocorridos na época em outras regiões do país: a apropriação senhorial de direitos de natureza fiscal ou jurisdicional, não atribuídos nas doações régias; a apropriação indevida de terrenos de antiga exploração comunitária; e a insistência na imposição de obrigações obsoletas, de raiz medieval.

${ }^{78}$ Id., id., mç. 793, doc. 31, resolução da Mesa de 15-2-1787. Id., id., mç. 793, doc. 35.

${ }^{79} \mathrm{O} 6^{\circ}$ visconde e $1^{\circ}$ conde de Barbacena foi Luís António Furtado de Castro do Rio de Mendonça e Faro (1754-1830). Filho do $5^{\circ}$ visconde, destacou-se como um dos principais dinamizadores da criação da Academia Real das Ciências de Lisboa. Em 1816 D. João VI deu-lhe o título de $1^{\circ}$ conde de Barbacena. Cf. Américo da Costa, Diccionario Chorographico ..., p. 162. Afonso Zúquete, Nobreza de Portugal e do Brasil, vol. 2, "Barbacena (Condes de)", p. 170-171. Sobre o seu papel na fundação da Academia das Ciências veja-se Theophilo Braga, Historia da Universidade de Coimbra nas suas Relações com a Instrucção Publica Portugueza, Tomo III. 1700 a 1800, Lisboa, Academia Real das Sciencias, 1898, pp. 645-664.

80 T.T./D.P. A.-A., mç. 793, doc. 35.

${ }^{81}$ Francisco Furtado de Castro do Rio de Mendonça e Faro (1780-1854), filho do $1^{\circ}$ conde. Cf. Afonso Zúquete, Nobreza de Portugal e do Brasil, vol. 2, "Barbacena (Condes de)", p. 171.

${ }^{82}$ A.M.E./ C.B., Livro de registo do foral e de provisões, provisão de 24-7-1830, para ter como juiz privativo o corregedor da comarca de Elvas, fls. 14. 
Tais abusos eram motivados pela ambição do reforço do poder senhorial, conjugada pelas crescentes dificuldades económicas, para as quais o agravamento das rendas e foros constituía o paliativo mais fácil e de efeitos mais imediatos; mas eram também facilitados por múltiplos factores: as ambiguidades e omissões dos textos de doação, de escrituras de compra e venda, ou de diplomas reguladores do direito de propriedade, da vida económica e do funcionamento das instituições locais; o medo, ignorância, boa fé ou alheamento dos povos; a falta de cultura jurídica dos eleitos camarários; e a influência local de uma clientela de ouvidores, procuradores, feitores, rendeiros, oficiais administrativos, cobradores de impostos ou simples criados dos donatários, que além de intimidarem e ameaçarem o povo, chegavam a dominar a vida local, através do controle das câmaras e das misericórdias.

Deste modo, os provedores e os corregedores (estes apenas nos senhorios não isentos de correição régia), eram, em princípio, os únicos garantes do cumprimento da lei geral, através da inspecção da actividade camarária e do modo de exercício do poder senhorial. Porém, a sobrecarga e a diversidade de competências destes ministros territoriais, a extensão das suas áreas de jurisdição, a escassez de meios repressivos e de outros recursos humanos e materiais, dificultavam consideravelmente a sua acção fiscalizadora, e facilitavam os abusos senhoriais ${ }^{83}$. Além do mais, condicionados, nas suas promoções, pelo resultado das sindicâncias que lhes eram efectuadas no final de cada mandato, estes magistrados de carreira, mesmo quando deparavam com situações de legalidade duvidosa, raramente ousavam enfrentar aqueles de quem dependia, em boa parte, a atestação do bom cumprimento das suas funções ${ }^{84}$.

Apenas a partir do pombalismo, com a legislação favorável à dignificação e ao reforço de competências destes importantes agentes da acção centralizadora e modernizadora do Estado, e com a simultânea perda de influência política da grande nobreza, foi possível reforçar a sua capacidade de controle da actividade

${ }^{83}$ Sobre a actividade destes magistrados de segunda instância e os factores condicionantes do seu exercício, veja-se: José Viriato Capela, Política de corregedores. A actuação dos corregedores nos municípios minhotos no apogeu e crise do Antigo Regime (1750-1834), Braga, Universidade do Minho, 1997; e Teresa Fonseca, Absolutismo e municipalismo. Évora. 1750-1820, Lisboa, Colibri, 2002, pp. 425-503.

${ }^{84}$ Sobre o modo de funcionamento dos autos de residência tirados a estes e outros magistrados régios no termo das suas funções, veja-se: José Manuel Louzada Lopes Subtil, O Desembargo do Paço (1750-1833), Lisboa, Universidade Autónoma, 1996, pp. 311-316; e ainda Teresa Fonseca, Absolutismo e municipalismo..., pp. 156-163. 
dos donatários, das câmaras e de outras instituições que mantinham, em relação a estes, alguma forma de dependência ${ }^{85}$.

Esta atitude mais interventiva dos ministros da coroa gerou nos povos um sentimento de segurança e confiança na protecção régia, o que favoreceu a emergência ou a intensificação das iniciativas anti-senhoriais, tanto no plano legal como no insurreccional.

Os donatários, incluindo os de Barbacena, imputavam, geralmente, as iniciativas de contestação do seu poder a uma minoria, na qual se incluía, frequentemente, o grupo da governança das terras; e procuravam isolá-los da maioria da população, acusando-os de a manipular apenas para defenderem interesses pessoais. De facto, quem tinha alguns bens, incluindo terra e gado, era naturalmente mais prejudicado pelas imposições fiscais ou pela defesa de terrenos comunitários. No entanto, tais acções afectavam toda a comunidade, que por isso confiava nos que entre eles possuíam alguma capacidade de iniciativa e de liderança, como sucedeu em Barbacena com Manuel da Ponte, João Antunes Borralho ou José Parreira.

A frequência do envolvimento activo dos elegíveis locais na contestação senhorial deve-se, por um lado, ao facto de pertencerem ao grupo social dos mais abastados e esclarecidos das localidades; mas também por compreenderem mais claramente os efeitos da interferência senhorial na autonomia do poder camarário. Com efeito, tal intromissão efectuava-se não só através da apresentação ou confirmação das pautas ou da apresentação ou dada dos ofícios administrativos, mas também pelas ingerências nas próprias decisões camarárias, pelo desrespeito sistemático das posturas ou pela apropriação abusiva do património concelhio ${ }^{86}$.

O poder senhorial representava igualmente um sério entrave ao desenvolvimento de uma pequena burguesia em ascensão, da qual faziam parte muitos destes "notáveis" locais, nomeadamente em Barbacena. Neste caso concreto, a fertilidade natural da terra, associada à proximidade geográfica tanto da fronteira como das importantes praças militares de Elvas e Campo Maior, proporcionava aos lavradores perspectivas aliciantes de lucro. Tais intenções eram, no entanto, contrariadas através das dificuldades impostas pelos senhorios ao negócio da criação de gado ou ao fabrico de pão para venda ${ }^{87}$; deste modo,

${ }^{85}$ Sobre a influência da legislação pombalina na intensificação da contestação anti-senhorial, veja-se Margarida Sobral Neto, Terra e conflito ..., pp. 179-240.

${ }^{86}$ Sobre esta problemática veja-se Teresa Fonseca, "Lavre e o seu município “, principalmente as pp. 62 a 71 .

${ }^{87}$ Os donatários apenas autorizavam o povo a utilizar os fornos domésticos para cozer o pão para consumo próprio (cf. T.T./D.P., A.-A., mç. 793, docs. 31 e 35), quando o foral de 1273 
os titulares afastavam a concorrência dos seus subordinados nestes negócios, embora granjeassem, em contrapartida, a sua animosidade e revolta.

Os problemas comuns às demais terras de domínio senhorial eram, em Barbacena, agravados pelo facto de a vila e o termo constituírem propriedade plena do donatário. Esta singularidade, embora em parte contestada pelos barbacenenses, reforçava consideravelmente os poderes dos donatários e limitava, no plano jurídico, a capacidade de intervenção da coroa. Daí as dificuldades, já sentidas na altura da reforma manuelina dos forais, em conciliar os direitos dos senhores outorgados na doação de D. João I, com os direitos do povo, atribuídos pelo instituidor da vila. Este obstáculo, responsável pela omissão das prerrogativas de natureza senhorial do foral reformado, acentuou-se com a alienação a Diogo de Castro do Rio e contribuiu decisivamente para o ambiente de permanente conflitualidade entre senhores e súbditos.

Podemos comprovar a importância atribuída pelos magistrados dos tribunais superiores à condição patrimonial de Barbacena pelo parecer emitido pelo procurador da coroa relativamente a um pedido de provisão formulado, em 1779 , pelo $5^{\circ}$ visconde, para coutar o termo da vila. O titular pretendia deste modo que apenas ele e os seus sucessores pudessem aí caçar, salvo as pessoas a quem ele próprio passasse licença para o efeito, com pena de prisão na cadeia de Elvas para os infractores.

O procurador da coroa, no parecer emitido sobre o requerimento, começava por declarar o carácter excepcional da mercê a conceder, pois o estabelecimento de coutadas era proibido pelas Ordenações do reino ${ }^{88}$. Não obstante, assinalava a existência de vários antecedentes, fundados "no merecimento particular", derivado dos "bons e distinctos serviços" feitos à coroa. Alegava que Francisco Furtado de Mendonça se encontrava nessa situação, "pella Illustre qualidade do seu sangue”, pelas acções relevantes praticadas pelo requerente e pelos seus ascendentes, por ser donatário de Barbacena e ainda "pella razão especial" das terras concelhias constituírem sua propriedade plena, "por huma verdadeira compra feita com próprio dezembolço" ${ }^{89}$.

determinava que os "moradores de Barbacena hajam livremente tendas, e fornos de Pam". A.M.E./ C.B., Livro de registo do foral e de provisões, fl. $4 \mathrm{v}$.

${ }^{88}$ Ordenações Filipinas, Liv $^{0}$ 5, Título 91.

${ }^{89}$ T.T./D.P. A.-A., mç. 816, doc. 137. O direito de coutagem foi-lhe concedido por provisão de 25-6-1779. 
O acentuado desequilíbrio de poder e de capacidade de influência entre as duas partes em litígio torna ainda mais surpreendente a persistência secular dos barbacenenses na defesa daquilo que consideravam constituir os seus direitos, sem se deixarem demover por ameaças, multas ou penas de prisão e de degredo.

O exemplo de conflitualidade anti-senhorial que acabamos de analisar ocorreu numa região considerada pouco expressiva no respeitante a fenómenos sociais desta natureza ${ }^{90}$. Duvidamos, contudo, que se trate de um caso isolado, pela sua duração e características. Talvez o forte incremento da investigação histórica sobre a região actualmente em curso venha a alterar essa ideia de aparente acalmia social, vivida nos domínios senhoriais alentejanos.

90 José Tengarrinha, Movimentos populares agrários em Portugal, vol. I-(1751-1807), p. 147; e vol. II - (1808-1825), p 323. 